\title{
The Cultivation of College Students' Innovation and Entrepreneurship Spirit
}

\author{
Wu Wenbin ${ }^{1}$, Wang Bixi ${ }^{2}$, and Yu Wenxuan ${ }^{3}$ \\ ${ }^{1}$ Communist Youth League Committee of Xi'an University, Xi'an, Shaanxi, China, 710065 \\ ${ }^{2}$ School of Arts of Xi'an University, Xi'an, Shaanxi, China, 710065 \\ ${ }^{3}$ School of Foreign Languages of Xi'an University, Xi'an, Shaanxi, China, 710065
}

Keywords: college students; innovation and entrepreneurship; cultivate

\begin{abstract}
Since "mass entrepreneurship and innovation" has been put forward, it has contributed to the important trend of Chinese college students' innovation and entrepreneurship. And with the relevant regulations and preferential policies issued by the Chinese government, the innovation and entrepreneurship of college students has become an important policy and development direction in China. As the successor of Chinese social construction, college students have become an important way to realize their own life value through innovation and entrepreneurship. So, this paper is of practical significance for the research on the cultivation of college students' innovation and entrepreneurship spirit. This paper mainly focuses on the cultivation of college students' innovation and entrepreneurship spirit, analyzes the value and significance of this spiritual cultivation, expounds the construction of the cultivation system of the spirit, and hopes that it can be helpful to the cultivation of innovation and entrepreneurship in Chinese colleges and universities.
\end{abstract}

\section{Introduction}

The cultivation of college students' innovation and entrepreneurship spirit is proposed in the current social context. Innovation and entrepreneurship can become a basic state policy of China, mainly based on the background of China's severe employment pressure and social and economic reform. Which is to find a solid road for social construction reform and promote the transformation of China's economic construction. The innovation and development of society cannot be separated from the cultivation of innovative talents. While the college students in Chinese universities have some innovation and entrepreneurship. However, there is no system and system in the whole, and there are some defects in the cultivation of college students' innovation and entrepreneurship. Which seriously restricts the cultivation of innovation and entrepreneurship spirit, and the innovation and entrepreneurial talents that influence the development of China. This paper mainly focuses on the cultivation of college students' innovation and entrepreneurship spirit, and analyzes the value and significance of this spiritual cultivation. And then perfect the cultivation way of this spirit. This is not only a great help for Chinese universities to foster innovation and entrepreneurship spirit. It is also helpful for college students to combine innovation and entrepreneurship knowledge with practice and devote themselves to innovation and entrepreneurship activities.

\section{The Value and Significance of Innovation and Entrepreneurship Spirit Cultivation of College Students}

\subsection{It is beneficial to cultivate the innovation and entrepreneurship quality of college students}

The quality of innovation and entrepreneurship is an indispensable part of students' personality in the process of innovation and entrepreneurship. It's also the behavioral pattern in its business, among them, the quality of innovation and entrepreneurship is mainly the spirit of teamwork, social responsibility and hard work. However, many of the current college students in the entrepreneurial process in the following phenomena, such as social sense of responsibility is weak, team cooperation consciousness is weak, and difficulties are hard to meet difficult. In the process of 
starting a business, the impact of innovation and entrepreneurial quality even seriously determines whether the entrepreneurial behavior of college students is successful. For a team with no sense of team, no hard work, no sense of social responsibility, the development of his entrepreneurial activities will be confronted with great difficulties, so it is very important to cultivate the quality of innovation and entrepreneurship of college students.

\subsection{It is conducive to the determination of innovation and entrepreneurship of college students}

The main purpose of Chinese universities' cultivation of innovation and entrepreneurship spirit for college students is to guarantee the successful development of their innovation and entrepreneurship activities. In the process of innovation and entrepreneurship, college students will meet all kinds of problems to solve. Such as financing difficulties, lack of legal knowledge, lack of operating experience, lack of financial knowledge, etc. In the face of these problems, how to solve the problem requires that entrepreneurs have a strong will of innovation and entrepreneurship. And the innovator who lacks these will be knocked down by reality and become a member of the entrepreneurial failure. There are some weaknesses in Chinese contemporary college students, such as strong dependence on psychology and lack of determination in entrepreneurship. Some entrepreneurs want to start a business but are afraid to fail. Once they have a problem, they think how to retreat. This negative and undetermined will be the biggest enemy of their failure. We must believe that firm innovation and entrepreneurship will be one of the important factors to ensure the success of college students. Only with a firm mind can we face up to problems and solve problems in the process of innovation and entrepreneurship full of twists and turns. Chinese colleges and universities must pay attention to the cultivation of students' innovation and entrepreneurial will, and cultivate their comprehensive spiritual quality and unyielding spirit.

\section{The Cultivation Way of College Students' Innovation and Entrepreneurship Spirit}

\subsection{Construction of innovation and entrepreneurship material culture}

The college spirit material culture is mainly reflected in the campus culture, teacher character and various propaganda of the school. We must integrate the ideas of innovation and entrepreneurship with the material culture, and transfer it to Chinese college students in the form of material culture. And then, we cultivate college students' innovation and entrepreneurship material culture. Chinese colleges and universities can make full use of the newspaper column, electronic screen and other propaganda channels to publicize the ideas and ideas of innovation and entrepreneurship. In this process, the preferential policies and application conditions for innovation and entrepreneurship should be interpreted. We will conduct a special interview and exhibition on the successful entrepreneurs of our school, and forming a positive and strong entrepreneurial culture atmosphere. We should spread innovation and entrepreneurship material culture through the university teachers. Through its own charm, teachers influence students' entrepreneurial ideas and spiritual cultivation, and arouse students' entrepreneurial awareness. At the same time, universities can promote the spiritual culture propaganda of colleges and universities by means of multimedia network. Regularly or regularly add innovation and entrepreneurship columns to the university's official website. This column makes real-time updates on the preferential policies and contents of entrepreneurship and enhances the understanding of college students.

\subsection{Cultivation of students' innovative thinking}

University teachers inspire the students to innovate the knowledge of entrepreneurship and the cultivation of innovative thinking by using heuristic teaching methods. And then induce college students to learn innovation and entrepreneurship knowledge consciously. In the course of guidance, through various ways to explore the problems of college students' innovation and entrepreneurship and the problems existing in the process of entrepreneurship. Finally inculcate the way of thinking for college students' innovative thinking and cultivate their innovative thinking at all times. Chinese university teachers encourage students to find problems, think problems and solve problems by 
adopting heuristic and inquiry-based teaching methods. Through this innovative way of thinking, we can improve our own problems and cultivate our own creative thinking through divergent thinking in multiple perspectives. In the process of teaching, students should be encouraged to develop innovative thinking and improve their learning efficiency.

\subsection{Practice to promote innovation and entrepreneurship}

Colleges and universities should strengthen the practice of innovation and entrepreneurship, and cultivate the innovation and entrepreneurship spirit of college students through practical training. We should let the college students experience the entrepreneurial process through innovative entrepreneurship practice teaching. In this process, we can predict the problems that could be encountered in the process of starting a business. Through the practice of theoretical contact, we can form the habit of discovering problems and solving problems. And then cultivate our own innovation and entrepreneurship spirit. For the application of the practice, colleges and universities can make corresponding business plan through social investigation, and organize the student team to carry out the business plan. Through the practice base of the school, we will train the students' team participating in the entrepreneurial program with their thoughts, abilities, qualities and physical strength. Through innovation and entrepreneurship practice, we can promote the cultivation of students' innovation and entrepreneurship, and enhance students' comprehensive ability and quality of innovation and entrepreneurship. The cultivation of innovation and entrepreneurship must be developed through long-term practice. So, we should pay attention to strengthen daily management in the process of college students' cultivation, and start from small things, and encourage college students to develop personalized development according to their own specialties. In addition, in the process of practicing exercise, the interdisciplinary approach should be used to promote innovation and entrepreneurship. Through different academic perspectives, research methods and theoretical guidance, we can cultivate students' innovative and entrepreneurial spirit.

\section{Conclusion}

In the socialist modernization drive today, entrepreneurship has sprung up in all walks of life. Under the slogan of "mass entrepreneurship and innovation", innovation and entrepreneurship has received wide attention from people from all walks of life, including government, society and school. Colleges and universities follow the central policy and social development trend, and set up innovation and entrepreneurship. The innovation and entrepreneurship competition with competition as the carrier is also carried out in various parts of the country like tea. The cultivation of innovation and entrepreneurship is the core of innovation and entrepreneurship education, which enables college students to build up their consciousness of innovation and entrepreneurship so that they can be spiritually sublimated.

\section{References}

[1] Bull I, GE Willard. Towards a theory of entrepreneurship. Journal of Bussiness Venturing (1993), p. 183 - 195

[2] PITT A, LEYLAND F. RUSHIEDA k The Role of Adapuaioll in Microenterprise Development: A Marketing Perspective. Journal of International Development (2000), p. 803 - 820

[3] Shane s. Prior Knowledge and the Discovery of Entrepreneurial Opportunities. Organization Science (2010), p. 448 - 469

[4] Knight F. Risk, Uncertainty, and Profit. Boston: Houghton Mifflin (1921), p. 211 - 213

[5] Semra Guven. World Conference on Edueational Seiences New primary edueationcourse programmes and entrepreneurship. Proeedia Social and Behavioral Seiences (2009), p. 265-270

[6] Helge Berglann; EsPenR. Moen, Knut Roed, etal. Entre Preneurship: Originsandreturns. Labour Eeonomies (2011), p. 180-193

[7] Roediger Voss. Thorsten Gruberjsabelle Szmigin."Service quality in higher education: Therole 
of student expectations". Journal of Business- Research (2007), p. 949-959 